\title{
Comparative study of the microbial diversity of bulk paddy soil of two rice fields subjected to organic and conventional farming
}

\author{
Ana R. Lopes ${ }^{a}$, Cátia Faria ${ }^{a}$, Ángeles Prieto-Fernández ${ }^{b}$, Carmen Trasar-Cepeda $^{\mathrm{b}}$, \\ Célia M. Manaia ${ }^{c}$, Olga C. Nunes ${ }^{\mathrm{a}, *}$ \\ a LEPAE, Dpto Engenharia Química, Faculdade de Engenharia, Universidade do Porto, 4200-465 Porto, Portugal \\ ${ }^{\mathrm{b}}$ Dpto Bioquímica del Suelo, IIAG-CSIC, Apartado 122, E-15780 Santiago de Compostela, Spain \\ ${ }^{\mathrm{c}}$ Escola Superior de Biotecnologia, Universidade Católica Portuguesa, 4200-072 Porto, Portugal
}

Keywords:

Cultivable microbial counts

Soil enzymatic activity

CLPP

DGGE fingerprinting

Bacterial community diversity

Agronomic management

\section{A B S T R A C T}

Two adjacent paddies of an experimental rice field, subjected to organic and conventional farming, were characterized aiming the comparative assessment of microbiological variations occurring in the bulk paddy soil over the rice cycle. This study comprehended the simultaneous characterization of general physicochemical soil properties [total carbon and nitrogen, $\mathrm{pH}\left(\mathrm{H}_{2} \mathrm{O}\right.$ and $\left.\mathrm{KCl}\right), \mathrm{C}: \mathrm{N}$ ratio and water content], biochemical properties [enzymatic activities and Community Level Physiological Profiles (CLPP)], the estimation of cultivable organisms (enumeration of fast growing heterotrophic bacteria, actinomycetes and fungi) and the assessment of bacterial diversity using a culture-independent method (PCR-DGGE fingerprinting). The linkage of the parameters measured was analysed by canonical correspondence analysis (CCA).

CCA ordination plots of the CLPP showed a similar pattern of microbial functional activity in both agronomic management systems, except in June. Enzymatic activity, water content and fungi counts were the main factors affecting the observed CLPP time variation. Such a variation was not expressed by the Shannon and evenness indices, which did not evidence significant differences in the bacterial and functional diversity between or within farming type over the analysed period. The cluster and CCA analyses of the DGGE profiles allowed the distinction of the bacterial communities of both paddies, with temporal variations being observed in the organically managed field but not in the conventional paddy. Enzymatic activity, $\mathrm{pH}$ and molinate content were the factors which most contributed to the observed variations. Altogether these results underline the functional redundancy of the rice paddy soil and evidence the temporal variations on the metabolic activity of soil, irrespective of farming type.

\section{Introduction}

Soil is a complex ecosystem where living organisms play a key role in the maintenance of its properties. Soil biota comprises a huge diversity of organisms belonging to different taxonomic and physiologic groups, which interact at different levels within the community. Soil microorganisms constitute a source and sink for nutrients and are involved in numerous activities, such as transformation of $C$, $\mathrm{N}, \mathrm{P}$ and $\mathrm{S}$, degradation of xenobiotic organic compounds, formation of soil physical structure and enhancement of plants' nutrient uptake (Gregorich et al., 1994; Seklemova et al., 2001). For these reasons, the

Corresponding author. Tel.: +351 225081917; fax: +351 225081449

E-mail address: opnunes@fe.up.pt (O.C. Nunes). importance of microorganisms in the maintenance of quality and productivity of agricultural soils is unquestionable. The responsiveness of microorganisms to environmental factors implies that disturbances imposed by agricultural treatments may lead to alterations in the composition and activity of soil microbiota and, therefore, may affect soil quality (Gregorich et al., 1994; Shibahara and Inubushi, 1997).

In the last decades, conventional management of agricultural soils, namely tillage and the utilization of synthetic fertilizers and plant protectors (pesticides), has been implemented worldwide, to improve the productivity and the quality of agricultural goods at low cost (Hasset and Banwart, 1992). Nevertheless, the recognition that intensive conventional farming promotes soil degradation (Liu et al., 2007; Mader et al., 2002), erosion (Eltun et al., 2002), and environmental contamination (e.g. Castro et al., 2005) led to 
a widespread interest in organic farming, with the natural control of pests and the utilization of compost and/or manure to substitute synthetic fertilizers (Mader et al., 2002; Shibahara and Inubushi, 1997). Over the last years, the effect of agricultural management practices on the soil properties and on crop yield has been widely studied in diverse types of agricultural soils (e.g. Liu et al., 2007; Mader et al., 2002; McCaig et al., 2001).

Rice paddy soil is considered a unique agro-ecosystem as it is kept flooded during the rice growth and is drained during the offcrop season. The rice paddy field comprises three compartments where the soil is subjected to different physical and chemical conditions: the oxic surface, the anoxic bulk and the rhizosphere plus rhizoplane (Liesack et al., 2000). Thus, the high diversity of habitats in the paddy field ecosystem offers a spatial and temporal heterogeneity, which enhances prokaryote specialization and division into distinct ecological niches (Henckel et al., 2001). Most of the microbiological studies in this type of ecosystem have been focused on the effect of oxygen concentration in the different field compartments, and on specific processes, particularly, methane emission and consumption, $\mathrm{N}_{2}$ fixation, $\mathrm{N}$ mineralization and sulphate reduction (Henckel et al., 2001; Liesack et al., 2000; Roger and Ladha, 1992; Shibahara and Inubushi, 1997; Wind and Conrad, 1997). Different fertilization regimes and the incorporation of organic residues are the most commonly addressed issues in studies focusing on agricultural management of paddy fields (Shibahara and Inubushi, 1997; Watanabe et al., 2006, 2007; Zhong and Cai, 2007). Nevertheless, comparative studies between conventional management and organic farming are scarce, if available, for rice fields. The worldwide extension and importance of this crop and the availability of an experimental rice field where such a comparison was being made, having in mind the assessment of productivity yields, made possible and motivated the current study.

In the present work, bulk soil from two adjacent paddies of an experimental rice field subjected to different management (organic and conventional) was compared. Our major goals were the comparison of the effect of the agricultural management on soil properties and the assessment of temporal variations. Specifically we intended to determine if the functional and bacterial diversity of soil varied over time and if such variations were similar irrespectively of the farming type. With this objective, soil subjected to different managements was sampled simultaneously at four different times over the rice cycle and was characterized using different approaches. The analyses carried out included the soil general characterization as well as measurements of biochemical properties, counts of total cell numbers and cultivable organisms and the assessment of bacterial diversity using a culture-independent method.

\section{Materials and methods}

\subsection{Experimental field}

The study was conducted in two adjacent paddy fields, each with three replicate plots, named I, II and III, from the experimental farm "Bico da Barca", from Direcção Regional de Agricultura e Pescas do Centro (DRAP Centro), located in the valley of river Mondego, Montemor-o-Velho, Central Portugal $\left(40^{\circ} 11^{\prime} \mathrm{N} ; 08^{\circ} 41^{\prime} \mathrm{W}\right)$. These fields have the same soil type and cropping system, but have received different soil management practices, organic (ORG) and conventional (CONV). Paddy field ORG $\left(4200 \mathrm{~m}^{2}\right)$ was under organic production for two years (2005-2007), and before it was uncultivated. Paddy field CONV $\left(7100 \mathrm{~m}^{2}\right)$ was subjected to conventional management for six consecutive years.

Rice was seeded in both fields in spring 2007 (Fig. 1). The field management of paddy ORG was as follows: basal fertilization with mineral gafsa (Fertigafsa, $300 \mathrm{~kg} \mathrm{P} \mathrm{ha}^{-1}$ ) and organic amendment with a plant residue commercial compost (Fertiormont, $2 \mathrm{t} \mathrm{ha}^{-1}$ ) in early April; flooding on 16th April; drainage and mechanical removal of weeds on 20th May; flooding on 21st May; seeding on 22nd May. The field management of paddy CONV was as follows: flooding on 19th April; seeding on 23rd April; molinate (Ordram, $50 \mathrm{~kg} \mathrm{ha}{ }^{-1}$ ) application on 26th April; drainage on 1st June; propanil (Stam, $18 \mathrm{~L} \mathrm{ha}^{-1}$ ) and bentazone (Basagram, $4 \mathrm{~L} \mathrm{ha}^{-1}$ ) application on 4th June; flooding on 6th June; and fertilization

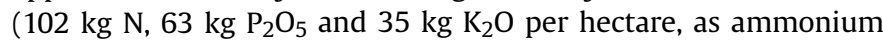
sulphate, ammonium dihydrogen phosphate and diammonium monohydrogen phosphate, and potassium chloride, respectively) on 8th June. Both paddies ORG and CONV were drained on 18th September, and harvested between 18th and 21st September.

\subsection{Soil sampling}

In both paddy fields, triplicate composite samples (each consisting of three different soil cores pooled together) were collected from the upper $0-15 \mathrm{~cm}$ of the soil from each of the three plots (I, II and III). The area of each plot of paddies ORG and CONV was of 1400 and $2367 \mathrm{~m}^{2}$, respectively. In order to assess possible modifications caused by the main agronomic management activities in the fields during the rice cycle, soil samples were collected on four occasions 23rd April, 2nd May, 13th June and 15th October of 2007. Soil samples were homogenized and cleaned by manual mixing of soil cores and removal of visible root debris, respectively. Soil samples were immediately processed for microbiological characterization or stored at $4{ }^{\circ} \mathrm{C}$ (for no more than 2 weeks) and $-20{ }^{\circ} \mathrm{C}$, before processing for biochemical and molecular characterization, respectively.

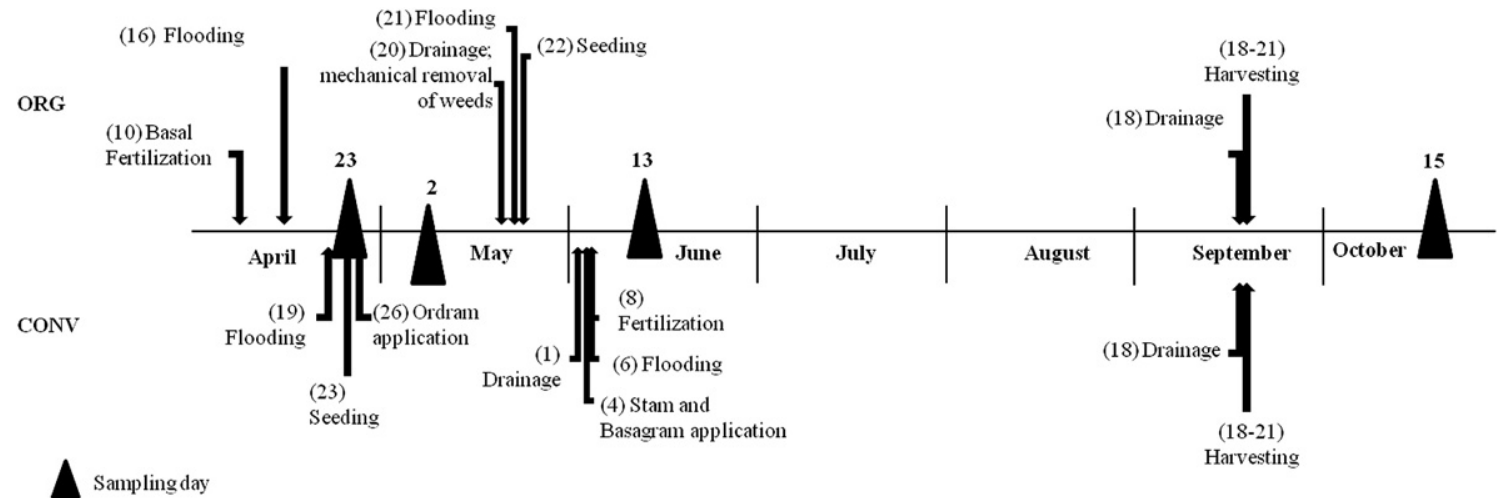

Fig. 1. Agricultural management procedures of paddy fields ORG and CONV and sampling dates. 


\subsection{General soil characterization}

The physical and the chemical properties of bulk soil were analysed following the procedures described by Guitián-Ojea and Carballas (1976). Briefly, total organic C was determined by wet oxidation with potassium dichromate, after treatment with $\mathrm{H}_{2} \mathrm{SO}_{4}$ to facilitate digestion of the organic matter and to ensure the removal of any inorganic $C$ present; total $\mathrm{N}$ was measured by the Kjeldahl digestion method and the $\mathrm{pH}$ in water and in $1 \mathrm{M} \mathrm{KCl}$ was determined in a soil:solution mixture $(1: 2.5 \mathrm{w}: \mathrm{v})$, with a glass electrode. Molinate concentration in bulk soil was determined by gas-chromatography-mass spectrometry, after soxhlet extraction with dichloromethane in Agência Portuguesa do Ambiente (http:// www.apambiente.pt).

\subsection{Enumeration of total cells and of cultivable microorganisms}

The enumeration of total cells from bulk soil was performed by the 4,6-diamidino-2-phenylindole (DAPI) staining method as described by Brunk et al. (1979). For each sample $10 \mathrm{~g}$ of soil were suspended in $90 \mathrm{ml}$ of sterile saline solution $(0.85 \% \mathrm{NaCl}, \mathrm{w} / \mathrm{v})$ and the mixture was stirred for $30 \mathrm{~min}$ at $200 \mathrm{rpm}$, sonicated (sonication bath) for $5 \mathrm{~min}$, and centrifuged at $3000 \mathrm{rpm}$ for $5 \mathrm{~min}$. The enumeration of total cells was performed in the supernatant, as described by Manuel et al. (2007).

Fast growing cultivable microorganisms were enumerated using the membrane filtration method. Serial dilutions of the soil suspensions were filtered through a $47 \mathrm{~mm}$ membrane with $0.45 \mu \mathrm{m}$ porosity (Knowles and Barraquio, 1994). The media Plate Count Agar (Merck), Actinomycetes Isolation Agar (Merck) and Rose Bengal-Chloramphenicol (Merck) were used, respectively, for the enumeration of fast growing heterotrophic bacteria, actinomycetes and fungi. Plate Count Agar and Actinomycetes Isolation Agar cultures were incubated at $30^{\circ} \mathrm{C}$ for $48 \mathrm{~h}$ and $7 \mathrm{~d}$, respectively; Rose Bengal-Chloramphenicol cultures were incubated at $22^{\circ} \mathrm{C}$ for $7 \mathrm{~d}$. Data from triplicates were expressed as colony forming units (CFU) $\mathrm{g}^{-1}$ dry soil (oven-dried soil basis).

\subsection{Soil enzymatic activities}

Dehydrogenase activity was determined with iodonitrotetrazolium violet (INT) as substrate, incubating with $1 \mathrm{M}$ TRIS- $\mathrm{HCl}$ buffer $\mathrm{pH} 7.5$ for $1 \mathrm{~h}$. The iodonitrotetrazolium formazan (INTF) produced was extracted with a 1:1 (v:v) mixture of ethanol and dimethylformamide and measured spectrophotometrically at $490 \mathrm{~nm}$. Activity was quantified by reference to a calibration curve constructed using INTF standards incubated with soil under the same conditions described above, and is expressed in $\mu$ mol INTF $\mathrm{g}^{-1} \mathrm{~h}^{-1}$ (Camiña et al., 1998). Catalase activity was determined according to the Trasar-Cepeda et al. (1999) modification of the method of Johnson and Temple (1964). The soil samples were incubated with $\mathrm{H}_{2} \mathrm{O}_{2}$ for 10 min and the residual $\mathrm{H}_{2} \mathrm{O}_{2}$ was determined by a colorimetric method. The activity is expressed in mmoles $\mathrm{H}_{2} \mathrm{O}_{2} \mathrm{~g}^{-1} \mathrm{~h}^{-1}$.

The activity of arylsulphatase was measured by using the method of Tabatabai and Bremner (1970), with minor modifications. Briefly, arylsulphatase activity was determined with 5 мм $p$ nitrophenyl sulphate as substrate, with $0.5 \mathrm{M}$ acetate buffer $(\mathrm{pH}$ 5.8). After incubating for $1 \mathrm{~h}$ at $37^{\circ} \mathrm{C}, 2 \mathrm{M} \mathrm{CaCl}$ was added and the liberated $p$-nitrophenol was extracted with $0.2 \mathrm{~m} \mathrm{NaOH}$. The enzymatic activity was quantified by reference to calibration curves corresponding to $p$-nitrophenol standards incubated with each soil under the same conditions as for the samples and the activity is expressed as $\mu \mathrm{mol} p$-nitrophenol $\mathrm{g}^{-1} \mathrm{~h}^{-1}$. The activity of urease was determined as described by Nannipieri et al. (1980). Briefly, urease activity was determined using $1065.6 \mathrm{~mm}$ urea as substrate, incubating for $1.5 \mathrm{~h}$ in $0.2 \mathrm{~m}$ phosphate buffer ( $\mathrm{pH} 8.0$ ), and measuring the $\mathrm{NH}_{4}^{+}$released with an ammonia electrode, and the enzyme activity is expressed as $\mu \mathrm{mol} \mathrm{NH} \mathrm{N}_{3} \mathrm{~g}^{-1} \mathrm{~h}^{-1}$. The activity of protease hydrolysing casein (casein-protease) was determined with $1 \%$ casein as substrate, incubating for $2 \mathrm{~h}$ in $0.05 \mathrm{~m}$ Tris(hydroxymethyl)aminomethane- $\mathrm{HCl}$ (TRIS- $\mathrm{HCl}$ ) buffer $(\mathrm{pH} \mathrm{9.0)}$ and the released amino acids determined by the Folin-Ciocalteu colorimetric method described by Ladd and Butler (1972), modified by Nannipieri et al. (1979). The casein-protease activity is expressed as $\mu \mathrm{mol}$ tyrosine $\mathrm{g}^{-1} \mathrm{~h}^{-1}$. Invertase activity was determined with $35.06 \mathrm{mM}$ saccharose as substrate, incubating for $3 \mathrm{~h}$, with $2 \mathrm{~m}$ acetate buffer ( $\mathrm{pH} 5.5$ ), the released reducing sugars determined following the method of Schinner and von Mersi (1990) and the enzymatic activity expressed as $\mu \mathrm{mol}$ glucose $\mathrm{g}^{-1} \mathrm{~h}^{-1}$.

All determinations were performed in triplicate and the average activity values were expressed on an oven-dried soil basis.

\subsection{Soil community level physiological profiles (CLPP) analysis}

The ability of microbial communities to utilize different $C$ substrates was determined using the method of Kennedy (1994). Five grams of each bulk soil replicate sample were suspended in $45 \mathrm{ml}$ of $1 \%$ sodium hexametaphosphate and shaken for $30 \mathrm{~min}$, vortexed at maximum speed for $1 \mathrm{~min}$ and serially diluted (1:10). Fifty microliter aliquots of the dilutions $10^{-2}-10^{-7}$ were inoculated in 96-well plates containing different $C$ sources (amines: $\beta$-phenyl ethylamine and putrescine; amino acids: L-arginine, L-asparagine; L-glutamic acid, L-phenylalanine, L-serine, L-threonine; carbohydrates: $\mathrm{D}-(+)$ cellobiose, $\alpha$-lactose, $\beta$-methyl D-glucoside, $\mathrm{D}-(+)$ xylose, i-erythritol, maltose, $N$-acetyl-D-glucosamine, glyceraldehyde; carboxylic acids: D-galactonic acid $\gamma$-lactone, galacturonic acid, o-hydroxybenzoic acid, p-hydroxybenzoic acid, malonic acid, $\alpha$-keto butyric acid, malic acid; polymers: Tween 40 , Tween $60, \alpha-$ cyclodextrin, glycogen and miscellaneous: $\alpha$-D-glucose-1-phosphate) and prepared as described by Kidd et al. (2008). Substrate utilization was indicated by colour development of the tetrazolium violet redox dye (2,5-diphenyl-3-( $\alpha$-naphthyl)tetrazolium chloride (TV), $0.15 \mathrm{mM}$ ) after $7 \mathrm{~d}$ of aerobic incubation at $25^{\circ} \mathrm{C}$. The total number of $C$ sources utilized was recorded and the number (MPN) of cells grown at each substrate was estimated using tables for 3 replicates per dilution level.

\subsection{Bacterial community analysis}

Bulk soil DNA was extracted from $0.25 \mathrm{~g}$ of soil using PowerSoil ${ }^{\mathrm{TM}}$ DNA Isolation Kit (MO BIO) with an additional incubation step at $65^{\circ} \mathrm{C}$ for $15 \mathrm{~min}$, after $40 \mathrm{~min}$ agitation at $1300 \mathrm{rpm}$. Quality of extracted DNA was controlled in 1\% agarose gels.

For PCR-DGGE profiling, a 500 bp fragment (based on the reference strain Escherichia coli bases 984 and 1378) was amplified using the 16S rRNA gene primers forward F984GC, containing a GC clamp (5'-CGC CCG GGG CGC GCC CCG GGC GGG GCG GGG GCA CGG GGG GAA CGC GAA GAA CCT TAC-3') and reverse R1378 (5'CGG TGT GTA CAA GGC CCG GGA ACG-3') (Heuer et al., 1997, clamp Nübel et al., 1996). The reaction mixtures $(50 \mu \mathrm{l})$ contained $2 \mu \mathrm{l}$ of target DNA, $0.5 \times$ PCR buffer with $50 \mathrm{mM} \mathrm{KCl}, 0.5 \times$ PCR buffer with $20 \mathrm{mM}\left(\mathrm{NH}_{4}\right)_{2} \mathrm{SO}_{4}, 0.4 \mathrm{mM}$ dNTP's, $3 \mathrm{mM} \mathrm{MgCl}$, 5\% DMSO, $0.6 \mu \mathrm{M}$ of each primer, and $3 \mathrm{U}$ taq DNA polymerase (Fermentas). Thermal cycling conditions were as follows: $5 \mathrm{~min}$ at $94{ }^{\circ} \mathrm{C}$, followed by 30 cycles of $30 \mathrm{~s}$ at $94{ }^{\circ} \mathrm{C}, 30 \mathrm{~s}$ at $64^{\circ} \mathrm{C}$ and $1 \mathrm{~min}$ at $72{ }^{\circ} \mathrm{C}$ and a final extension step of $30 \mathrm{~min}$ at $72^{\circ} \mathrm{C}$. Amplified products were quantified in Qubit $^{\circledR}$ Fluorometer (Invitrogen) with Quant-iT ${ }^{\mathrm{TM}}$ dsDNA HS assay kit. 
Amplified bacterial 16S rRNA gene fragments ( 75 ng of DNA) were separated in a double gradient polyacrylamide gel containing 6-9\% acrylamide, to improve band resolution (Cremonesi et al., 1997 ) and a gradient of $30-58 \%$ of denaturant ( $100 \%$ denaturant corresponds to $7 \mathrm{M}$ urea and $40 \%(\mathrm{v} / \mathrm{v}$ ) formamide), using D-code System (Bio-Rad). The electrophoresis run in $1 \times$ TAE buffer at $60^{\circ} \mathrm{C}$ at a constant voltage of $200 \mathrm{~V}$ for $6 \mathrm{~h}$ and was preceded by a pre run at $60 \mathrm{~V}$ for $30 \mathrm{~min}$. The DGGE gels were silver-stained according to Heuer et al. (1997).

\subsection{Statistical analyses}

Scanned DGGE gels were analysed with the Bionumerics software (version 6.0, Applied Maths, Belgium). DGGE gels were normalized using a standard reference sample, which was loaded in 3 lanes in every gel. Samples were compared after band-matching analysis in the area $19.3-84.2 \%$ of the gel. Bands were assigned to classes of common bands within all profiles, and band-matching tables based on densitometric values were obtained. These bandmatching tables were the basis for community cluster and ordination analysis and for the determination of diversity indices. Similarity between fingerprints was calculated using the Pearson product moment correlation coefficient and dendrograms were generated using the unweighted pair-group method with arithmetic averages (UPGMA).

Canonical Correspondence Analysis (CCA) was carried out in order to assess the influence of general soil properties, biochemical and microbiological parameters (explanatory variables) on the variance of the bacterial community composition (DGGE patterns) or microbial functional activity (growth on single $C$ source), within and between the soil of paddies ORG (paddy ORG) and CONV (paddy CONV), over the rice cycle. CCA was performed using PCORD (version 5, MJM Software, Gleneden, USA). The significance of the relationship between community data (principal matrix) and the environmental data (second matrix) was tested by Monte Carlo permutations test $(n=999)$.

Explanatory variables included in both CCA analyses were selected by manual forward selection including the permutation test (Monte Carlo permutations test). All the soil properties and biochemical and microbiological parameters for which the null hypothesis was excluded $(P<0.05)$ were included in the ordination.

Abiotic parameters, microbial counts, enzymatic activity and diversity indices within each paddy were compared using a twoway analysis of variance (ANOVA) in function of the sampling time. The post-hoc Tukey test was applied when adequate. Paddies ORG and CONV were also compared using the two-sample statistical test (t-test). The statistical analyses were done using Excel software package (Microsoft Excel).

\subsection{Analysis of soil functional and structural diversity}

The structural and functional diversity of the microbial community was assessed using the Shannon index of diversity $\left(H=-\Sigma\left(\mathrm{n}_{\mathrm{i}} / \mathrm{N}\right) \log \left(\mathrm{n}_{\mathrm{i}} / \mathrm{N}\right)\right.$; Shannon and Weaver, 1963) and the evenness index $(E=\mathrm{H} / \log S$; Pielou, 1966). For the bacterial community analysis, the number of DGGE bands corresponded to the number of species $(S)$ in each sample while for the functional analysis, the number of substrates metabolised $(S)$ in CLPP analysis corresponded to the number of carbon sources used for growth by each sample. The relative surface intensity of each DGGE band or the $\log$ MPN g ${ }^{-1}$ value associated with each substrate $\left(n_{i}\right)$ and the sum of all the surface band intensity or of all the $\log \mathrm{MPN} \mathrm{g}^{-1}$ values associated with substrates used in a given sample $(N)$ were used, respectively, as estimates of species abundance or extent of its use (Fromin et al., 2002).

\section{Results}

\subsection{General soil characterization}

Among the physicochemical parameters analysed in the paddies ORG and CONV, water content varied significantly throughout the rice cycle $(P<0.01)$ (Table 1$)$. As could be anticipated, the average water content values were lower in October, when the two paddies were drained. In spite of some minor differences, paddies ORG and CONV differed significantly only for $\mathrm{pH}$, in April and for the water content, in May and June. In April, $\mathrm{pH} \mathrm{H}_{2} \mathrm{O}$ and $\mathrm{pH} \mathrm{KCl}$ values were higher in paddy ORG than in CONV $(P<0.05)$. In comparison with paddy CONV, paddy ORG water content was higher in May and lower in June $(P<0.05)$. As expected, molinate was detected only in paddy CONV; the highest concentration was found immediately after its application, being also detected about one month later.

\subsection{Total and cultivable microorganisms}

In paddy ORG the number of total cells did not vary significantly over the rice cycle (Table 2). In contrast, cultivable microorganisms varied significantly throughout the period under study. In June the number of heterotrophs was higher than in April $(P<0.05)$ but was not different from those of May or October. The number of actinomycetes reached its maximum in June $(P<0.05)$ although not significantly different from October. The number of fungi was also higher in June and October $(P<0.05)$ than in April and May.

Table 1

Main physical and chemical properties of soil of paddies ORG and CONV. Values are means \pm standard deviation $(n=3)$.

\begin{tabular}{|c|c|c|c|c|c|c|c|c|}
\hline \multirow[t]{2}{*}{ Parameter } & \multicolumn{2}{|l|}{ April } & \multicolumn{2}{|l|}{ May } & \multicolumn{2}{|l|}{ June } & \multicolumn{2}{|l|}{ October } \\
\hline & ORG & CONV & ORG & CONV & ORG & CONV & ORG & CONV \\
\hline $\mathrm{pH} \mathrm{H}_{2} \mathrm{O}$ & $6.44 \pm 0.17^{\mathrm{A} *}$ & $5.67 \pm 0.35^{\mathrm{A} *}$ & $6.32 \pm 0.05^{\mathrm{A}}$ & $6.21 \pm 0.09^{A}$ & $6.33 \pm 0.15^{\mathrm{A}}$ & $6.00 \pm 0.27^{\mathrm{A}}$ & $6.23 \pm 0.02^{\mathrm{A}}$ & $6.03 \pm 0.29^{A}$ \\
\hline $\mathrm{pH} \mathrm{KCl}$ & $4.78 \pm 0.09^{\mathrm{A} *}$ & $4.34 \pm 0.25^{\mathrm{A} *}$ & $5.01 \pm 0.21^{\mathrm{A}}$ & $4.76 \pm 0.20^{\mathrm{A}}$ & $4.92 \pm 0.03^{A}$ & $4.78 \pm 0.33^{A}$ & $4.88 \pm 0.06^{\mathrm{A}}$ & $4.49 \pm 0.31^{\mathrm{A}}$ \\
\hline Total C (\%) & $1.91 \pm 0.13^{\mathrm{A}}$ & $1.94 \pm 0.24^{\mathrm{A}}$ & $1.83 \pm 0.19^{A}$ & $2.14 \pm 0.11^{\mathrm{A}}$ & $1.76 \pm 0.45^{\mathrm{A}}$ & $2.25 \pm 0.36^{\mathrm{A}}$ & $1.43 \pm 0.14^{\mathrm{A}}$ & $1.74 \pm 0.35^{\mathrm{A}}$ \\
\hline Total N (\%) & $0.17 \pm 0.02^{\mathrm{A}}$ & $0.18 \pm 0.01^{\mathrm{A}}$ & $0.18 \pm 0.02^{\mathrm{A}}$ & $0.19 \pm 0.01^{\mathrm{A}}$ & $0.16 \pm 0.01^{\mathrm{A}}$ & $0.17 \pm 0.02^{\mathrm{A}}$ & $0.16 \pm 0.01^{\mathrm{A}}$ & $0.16 \pm 0.01^{\mathrm{A}}$ \\
\hline $\mathrm{C} / \mathrm{N}$ & $12 \pm 1^{\mathrm{A}}$ & $11 \pm 1^{\mathrm{A}}$ & $10 \pm 0^{\mathrm{A}}$ & $11 \pm 1^{\mathrm{A}}$ & $11 \pm 3^{A}$ & $14 \pm 1^{\mathrm{A}}$ & $9 \pm 1^{\mathrm{A}}$ & $11 \pm 3^{A}$ \\
\hline $\begin{array}{l}\text { Water content }(\%)\left(\mathrm{g} \mathrm{H}_{2} \mathrm{O} / 100\right. \\
\text { g wet soil) }\end{array}$ & $35.9 \pm 0.6^{C}$ & $36.4 \pm 0.8^{\mathrm{B}}$ & $35.7 \pm 0.3^{\mathrm{C} *}$ & $34.1 \pm 0.9^{\mathrm{B} *}$ & $28.2 \pm 0.7^{\mathrm{B} *}$ & $37.6 \pm 2.3^{\mathrm{B} *}$ & $24.7 \pm 1.1^{\mathrm{A}}$ & $25.0 \pm 0.9^{\mathrm{A}}$ \\
\hline Molinate $\left(\mathrm{mg} \mathrm{kg}^{-1}\right)$ & $<0.050^{\mathrm{A}}$ & $<0.050^{\mathrm{A}}$ & $<0.050^{\mathrm{A} *}$ & $0.297 \pm 0.005^{\mathrm{C} *}$ & $<0.050^{\mathrm{A} *}$ & $0.163 \pm 0.003^{\mathrm{B} *}$ & $<0.050^{\mathrm{A}}$ & $<0.050^{\mathrm{A}}$ \\
\hline
\end{tabular}

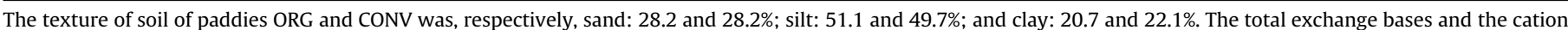

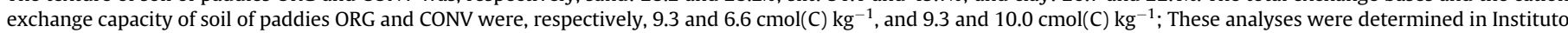

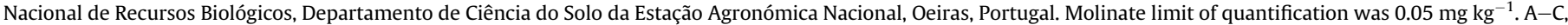

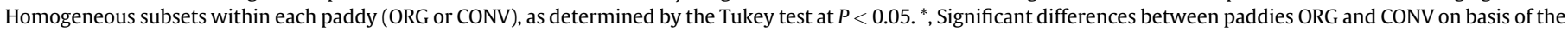
two-sample $t$-test at $P<0.05$. 
Table 2

Enumeration of heterotrophic bacteria, actinomycetes and fungi in soil of paddies ORG and CONV over the rice cycle. Values are means \pm standard deviation ( $n=3$ ).

\begin{tabular}{|c|c|c|c|c|c|c|c|c|}
\hline & \multicolumn{2}{|l|}{ Total cells } & \multicolumn{2}{|c|}{ Heterotrophs } & \multicolumn{2}{|c|}{ Actinomycetes } & \multicolumn{2}{|l|}{ Fungi } \\
\hline & \multicolumn{2}{|l|}{$\log$ Cells $\mathrm{g}^{-1}$} & \multicolumn{6}{|l|}{$\log C F U g^{-1}$} \\
\hline & ORG & CONV & ORG & CONV & ORG & CONV & ORG & CONV \\
\hline April & $8.0 \pm 0.2^{\mathrm{A}}$ & $7.9 \pm 0.1^{\mathrm{A}}$ & $5.0 \pm 0.6^{\mathrm{A}}$ & $5.6 \pm 0.4^{\mathrm{A}}$ & $5.2 \pm 0.3^{\mathrm{A}}$ & $5.5 \pm 0.6^{\mathrm{A}}$ & $3.4 \pm 0.3^{\mathrm{A}}$ & $3.7 \pm 0.3^{\mathrm{A}}$ \\
\hline May & $7.9 \pm 0.2^{\mathrm{A}}$ & $7.8 \pm 0.1^{\mathrm{A}}$ & $5.7 \pm 0.2^{\mathrm{A}, \mathrm{B}}$ & $5.5 \pm 0.3^{\mathrm{A}}$ & $5.3 \pm 0.4^{\mathrm{A}}$ & $5.4 \pm 0.6^{\mathrm{A}}$ & $3.2 \pm 0.1^{\mathrm{A}}$ & $3.4 \pm 0.6^{\mathrm{A}}$ \\
\hline June & $7.7 \pm 0.1^{\mathrm{A} *}$ & $8.1 \pm 0.1^{\mathrm{B} *}$ & $6.4 \pm 0.2^{\mathrm{B}}$ & $6.4 \pm 0.3^{\mathrm{B}}$ & $6.3 \pm 0.3^{B}$ & $6.1 \pm 0.3^{A}$ & $4.6 \pm 0.1^{B}$ & $4.2 \pm 0.4^{\mathrm{A}}$ \\
\hline October & $8.1 \pm 0.1^{\mathrm{A}}$ & $8.2 \pm 0.1^{\mathrm{B}}$ & $5.8 \pm 0.2^{\mathrm{A}, \mathrm{B}}$ & $5.9 \pm 0.2^{\mathrm{A}, \mathrm{B}}$ & $5.6 \pm 0.3^{\mathrm{A}, \mathrm{B}}$ & $5.6 \pm 0.3^{A}$ & $4.3 \pm 0.4^{\mathrm{B}}$ & $4.3 \pm 0.3^{\mathrm{A}}$ \\
\hline
\end{tabular}

A-B, Homogeneous subsets within each paddy (ORG or CONV), as determined by the Tukey test at $P<0.05$.

*Significant differences between paddies ORG and CONV on basis of the two-sample $t$-test at $P<0.05$.

In paddy CONV the total number of cells was higher in June and October than in April and May $(P<0.05)$. Among the cultivable populations, only the number of heterotrophs varied significantly over the rice cycle, with higher counts in June than in April and May $(P<0.05)$, but not significantly different from those observed in October.

When comparing both paddies, the only significant difference was observed in June, when the total number of cells was slightly higher for paddy CONV than for paddy ORG $(P<0.05)$.

\subsection{Soil enzymatic activities}

Four out of the six enzymatic activities analysed presented significant temporal variations both in ORG and CONV paddies. Urease and catalase activities presented significant variations in both paddies, with the highest value in May. Activity of invertase showed similar variations in both paddies though changes were only significant for paddy ORG; the highest value was registered in April, although not significantly different from that observed in May and October. Dehydrogenase activity varied in paddy CONV, with its maximum in June (Table 3 ).

When paddies ORG and CONV were compared for their patterns of enzymatic activity it was observed that in April paddy CONV showed a higher urease activity than paddy ORG $(P<0.05)$. In May, the dehydrogenase activity was higher in paddy ORG than in paddy CONV $(P<0.05)$ and in October, arylsulphatase activity was higher in paddy CONV than in paddy ORG $(P<0.05)$.

\subsection{Soil community level physiological profiles (CLPP) analysis}

All substrates analysed supported the growth of the microbial communities of both paddies and in every sampling time studied (Fig. 2). The average values of Shannon index $(H)$ and of evenness index $(E)$ for functional diversity in both paddies were respectively of 1.44 and of 1.00 . No significant differences between paddies or over time were observed for these indices (Table 4).

The highest MPN of microorganisms growing on the 21 out of the 28 analysed substrates, was registered in June for both paddies (Fig. 2). The exceptions were maltose, putrescine, o-hydroxybenzoic and p-hydroxybenzoic acid, D- $(+)$ xylose, D-(+)cellobiose, L-asparagine. The lowest values were observed in October, except for glycogen, L-serine, $\alpha$-lactose, galacturonic acid in paddy ORG and $\alpha$-keto butyric acid, $\beta$-methyl D-glucoside, L-glutamic acid, D-galactonic acid $\delta$-lactone in paddy CONV.

In the CCA biplot, the total variance in the CLPP data explained by axis 1 and 2 was $73.4 \%$ (53.8 and 19.6\%, respectively) (Fig. 3). The species-environmental correlations were high, with values of 0.999 and 0.967 for axis 1 and 2 , respectively $(P=0.001)$. The temporal variation of the community functional activity of both soils was explained mostly by the urease activity, the fungi counts, which presented high intraset correlations with axis $1(-0.791$ and 0.715 , respectively) and the catalase activity and soil water content, which presented higher intraset correlations with axis $2(-0.730$ and 0.591, respectively). Except in June, paddies ORG and CONV showed a similar pattern of microbial functional diversity temporal variation. Malonic $(-0.615, P<0.001)$ and o-hydroxybenzoic $(-0.517$, $P<0.001)$ acids, for which higher MPN values were registered in May than in October in both paddies, were among the substrates that most contributed to the variation observed along axis 1 . Glycogen $(-0.796, P<0.001)$, L-asparagine $(-0.720, P<0.001)$, and putrescine $(-0.711, P<0.001)$ were the substrates that most contributed to the variation observed along axis 2 . For these substrates, the lowest MPN values were registered in April in both paddies, whereas in June, higher MPN values were observed in paddy ORG than in paddy CONV.

\subsection{DGGE analysis of soil bacterial community}

The analysis of DGGE profiles based on the diversity of 16S rRNA bacterial gene sequence revealed complex band patterns for both paddies and for every analysed period. Considering the totality of the DGGE profiles, a total of 38 well resolved bands were detected and assigned, with, in average, 23 bands in each DGGE profile. In general, the number of bands detected simultaneously at different sampling dates was higher in paddy CONV (13 bands) than in paddy ORG (6 bands), and among these, only two were common to both paddies and persistent over time. Most of the bands were detected in both paddies, although at different sampling periods, or with different intensities. Cluster analyses of DGGE profiles of both soils showed the separation between the paddy ORG and paddy CONV bacterial communities (Fig. 4).

The Shannon index of diversity $(H)$ and the evenness index $(E)$ values to evaluate the bacterial diversity are shown in Table 4 . Shannon' index presented an average value of 1.28 and 1.26 , for paddies ORG and CONV, respectively. The $E$ values ranged between 0.93 and 0.95 for paddy ORG and between 0.91 and 0.93 for paddy CONV. The analysis of variance of these indices did not reveal significant differences within each paddy for the different analysed periods, or between them in each sampling time.

In the CCA ordination analysis of DGGE band patterns, the total variance of the data explained by axes 1 and 2 was $20.7 \%$ and $12.2 \%$, respectively. Both axes presented high species-environment correlation values (0.966 and 0.899 , for axis 1 and 2 , respectively) $(P=0.001)$. The CCA biplot allowed the distinction of four groups (I-IV) of samples (Fig. 5). Group I enclosed all the paddy ORG patterns from May and June. Group II was constituted by all paddy CONV patterns, except two samples from June and two from October. Group III included all the paddy ORG patterns from October. Finally, Group IV included paddy ORG patterns from April. The activity of catalase and invertase, as well as the heterotrophic counts, which presented an intraset correlation of, respectively, $-0.698,0.478$ and -0.456 with axis 1 contributed to separate group I from all the others. On the other hand, $\mathrm{pH}\left(\mathrm{H}_{2} \mathrm{O}\right)$, urease activity and molinate concentration, which presented an intraset correlation of, 
respectively, $-0.682,0.595$ and 0.496 with axis 2 contributed to delineate groups II, III and IV.

\section{Discussion}

Several physicochemical, biochemical and microbiological parameters were determined concurrently for paddies ORG and CONV over the rice cycle. With these analyses we aimed at assessing possible temporal variations for each of the studied agricultural procedures and the influence of the agricultural management on the soil properties. The agricultural management of paddy field ORG included a period (April-late May) of weeds growth. This is part of the management process in which weeds overgrowth during rice cultivation is prevented by its previous growth and subsequent mechanical removal. Thus, from April to June both weeds and rice plants grew in this field. Given the management of paddy field CONV, for this soil, the samples from April to June corresponded to different stages of the rice growth, and included the phytosanitary treatments (molinate in May and propanil and bentazone in June) and synthetic fertilization (in June). In both paddies, the samples of October corresponded to upland conditions, after harvesting. Among the biochemical and physicochemical parameters and microbiological counts determined between April and October, a similar trend of variation was observed for both paddies. In general, independently of the management practice, enzymatic activity reached the maximum in May and the cultivable organisms in June. In October the values of most of the measured parameters were, in general, lower than in May and/or June, but higher than in April.

The CLPP and DGGE profile-based richness of soil of paddies ORG and CONV were similar over the rice cycle, with all the sole C substrates being used for growth and the same average number of DGGE bands being present at all the sampling periods for both paddies. Moreover, the Shannon and the evenness diversity indices based on the CLPP and DGGE profiles did not vary in each paddy over time or differed between paddies at each sampling time. These results suggest heterogeneity and co-abundance of different organisms in rice soil with high functional diversity, irrespectively of farming type. In fact, the high functional diversity of rice field soil was previously reported (Zhou et al., 2008), and it is known that this highly heterogeneous habitat favours the growth and survival of versatile bacterial members. Hence, these organisms contribute to a diverse community, which contrasts with the restricted bacterial communities observed in percolating water and rice roots (Asakawa and Kimura, 2008; Kikuchi et al., 2007).

Given the fact that similar diversity indices were observed in both paddies, together with an identical over time trend of variation of the analysed parameters, it could be argued that the type of agricultural management practice did not have a major influence on the functional and microbial communities of the rice soil. In fact, among the microbial counts and the biochemical and physicochemical parameters determined, only a few were observed to differ significantly between both management systems. Some of the differences found, as the water content in May and June, were probably due to field management, rather to intrinsic soil properties. The scarcity of other studies comparing conventional (pesticides application and synthetic fertilization) and organic rice farming (no pest control, mineral and organic amendments) limits a deeper discussion of our data. However, the parameters that differed between paddies ORG and CONV ( $\mathrm{pH}$, the activity of some enzymes and the total cell counts) are reported in literature as being susceptible of variation between organically and conventionally farmed soils. The higher values of $\mathrm{pH}$ registered for paddy ORG than for paddy CONV, particularly in April, is in accordance to that described in the literature when comparing different 

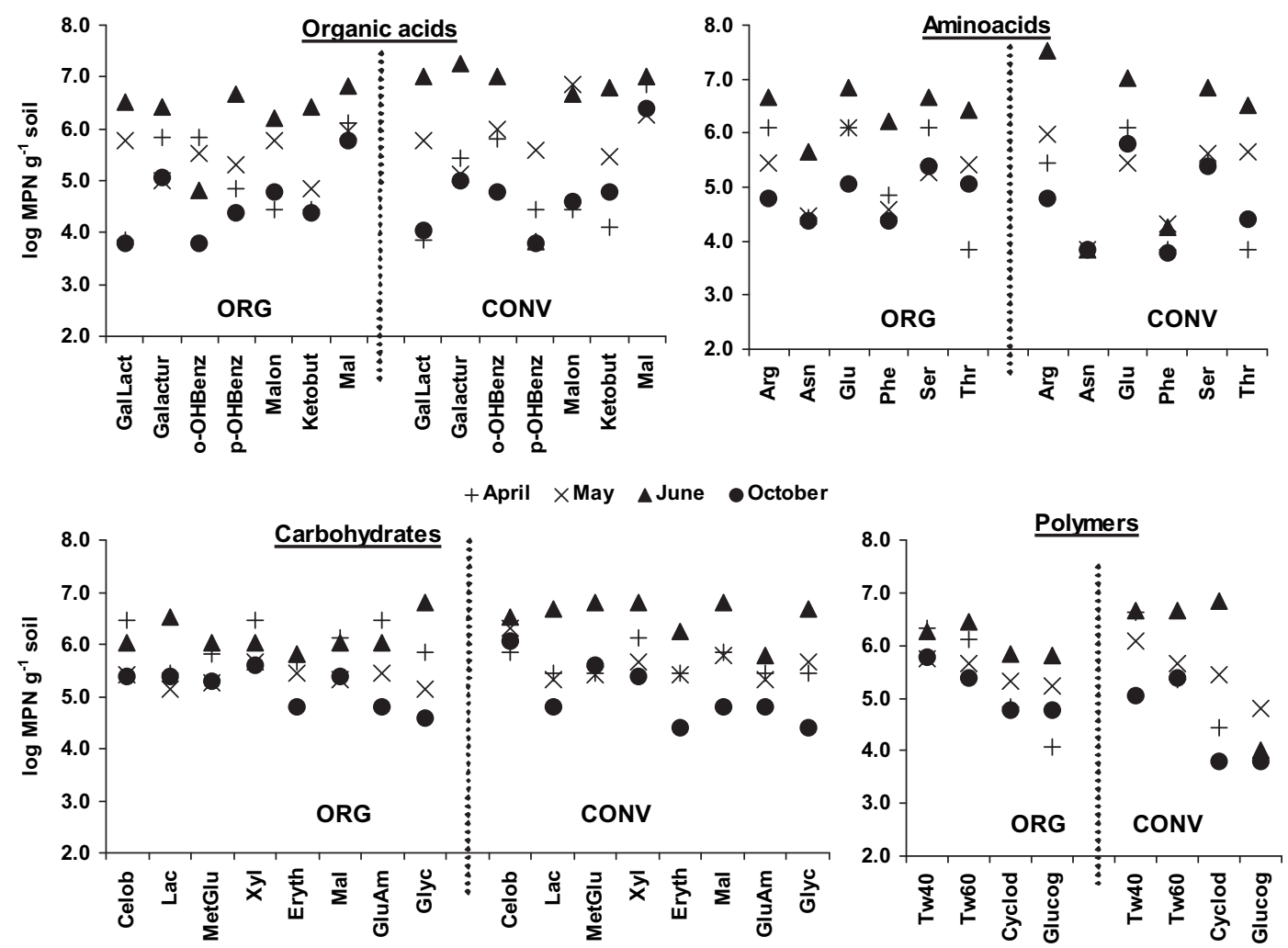

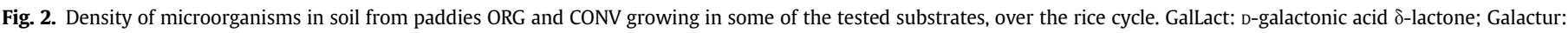

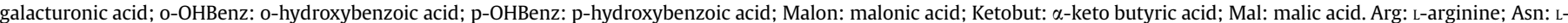

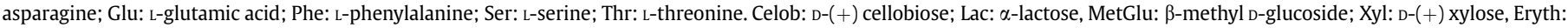
i-erythritol, Mal: maltose; GluAm: $N$-acetyl-D-glucosamine, Gly: glyceraldehyde. TW40: Tween 40; Tw60: Tween 60; Cyclod: $\alpha$-cyclodextrin; Glucog: glycogen.

agricultural management procedures. In fact, in previous studies, organically farmed soils present slightly higher $\mathrm{pH}$ values than conventionally managed soils (e.g. Mader et al., 2002; Liu et al., 2007). Several authors reported that organic management practices may lead to increased soil microbial biomass, activity and microbial functional and taxonomic richness and diversity when compared to conventional farming (Carpenter-Boggs et al., 2000; Mader et al., 2002; van Diepeningen et al., 2006). Nevertheless, none of the previous studies referred to above have focused on rice cultures. In our study, no differences were found between both managements in what respects functional and bacterial community richness and diversity. Additionally, assuming that the microbial biomass can be related to the microbial counts, the results obtained in the present study for rice soil did not follow the pattern described by other authors, who compared different agricultural procedures for other crops (Carpenter-Boggs et al., 2000; Mader et al., 2002; van Diepeningen et al., 2006). In contrast, rice field soil studies of Sheng et al. (2005), although not comparing organic with conventional farming, are in agreement with ours. Given the uniqueness of the rice culture, which includes a long period of flooded conditions, it would not be surprising that farming management might trigger different responses in soil communities, than those observed in other crops. In a comparative study of the effects of synthetic fertilization and/or pesticides use, Sheng et al. (2005) reported that the microbial biomass and the number of heterotrophic bacteria in rice field soil subjected to incorporation of synthetic fertilizers alone was not significantly different from rice field soil under conventional farming (synthetic fertilization and pesticides), although enhanced dehydrogenase activity was observed in the first soil. Additionally, Sheng et al. (2005) observed that the highest number of heterotrophs in both soils was at tillering stage, which is in agreement with our study, as in June rice plants were at the same growth stage. Interestingly, the highest MPN of microorganisms growing in the sole $C$ substrates tested was coincident with the highest counts of fast growing heterotrophs and actinomycetes. This observation may be related with enhanced

Table 4

Diversity indices of microbial communities in soil of paddies ORG and CONV over the rice cycle.

\begin{tabular}{|c|c|c|c|c|c|c|c|c|}
\hline & \multicolumn{4}{|c|}{ Bacterial diversity } & \multicolumn{4}{|c|}{ Functional diversity } \\
\hline & \multicolumn{2}{|c|}{ Shannon index $(H)$} & \multicolumn{2}{|l|}{ Evenness $(E)$} & \multicolumn{2}{|c|}{ Shannon index $(H)$} & \multicolumn{2}{|c|}{ Evenness $(E)$} \\
\hline & ORG & CONV & ORG & CONV & ORG & CONV & ORG & CONV \\
\hline April & $1.26 \pm 0.02$ & $1.24 \pm 0.03$ & $0.93 \pm 0.02$ & $0.91 \pm 0.02$ & 1.44 & 1.44 & 1.00 & 0.99 \\
\hline May & $1.28 \pm 0.04$ & $1.26 \pm 0.06$ & $0.94 \pm 0.01$ & $0.92 \pm 0.02$ & 1.43 & 1.43 & 1.00 & 1.00 \\
\hline June & $1.27 \pm 0.03$ & $1.25 \pm 0.05$ & $0.93 \pm 0.02$ & $0.93 \pm 0.03$ & 1.45 & 1.44 & 1.00 & 0.99 \\
\hline October & $1.29 \pm 0.03$ & $1.27 \pm 0.06$ & $0.95 \pm 0.01$ & $0.91 \pm 0.03$ & 1.44 & 1.44 & 1.00 & 1.00 \\
\hline
\end{tabular}

No significant differences were observed over the sampling period $(P \geq 0.05)$. 


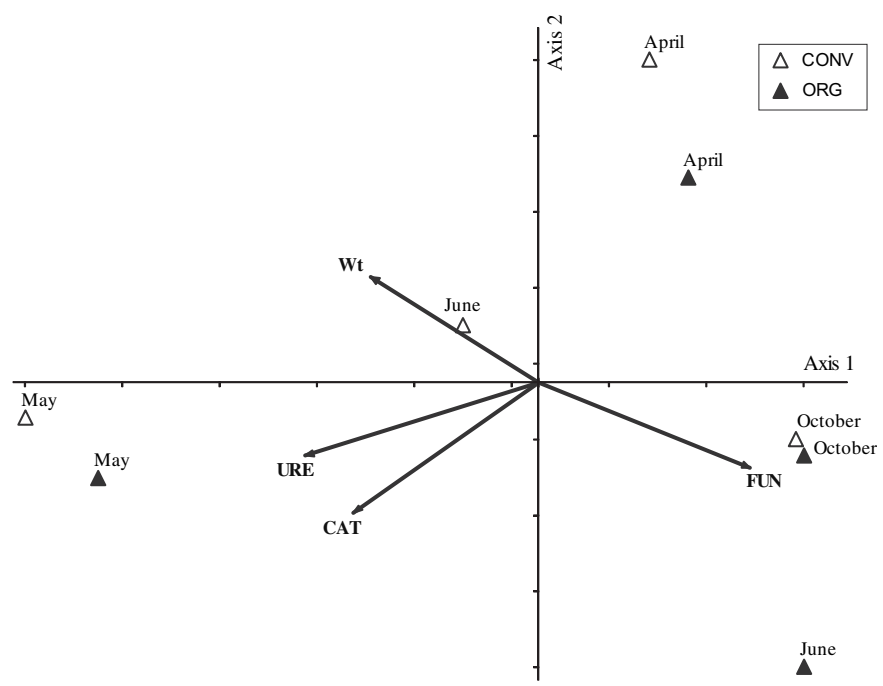

Fig. 3. Canonical correspondence analysis biplot of CLPP of soil from paddies ORG and CONV and physical, (bio)chemical and microbiological parameters (represented by arrows) throughout the rice cycle. CAT, catalase activity (mmol $\mathrm{H}_{2} \mathrm{O}_{2} \mathrm{~g}^{-1} \mathrm{~h}^{-1}$ ), URE, urease activity ( $\mu$ mol $\mathrm{NH}_{3} \mathrm{~g}^{-1} \mathrm{~h}^{-1}$ ); Wt, water content (\%); FUN fungi counts $\left(\log\right.$ CFU g ${ }^{-1}$ soil).

availability of labile $\mathrm{C}$ and $\mathrm{N}$ in both soils in June. In this period, rice plants were growing towards maturation in both paddies, and the highest density of cultivable bacteria and microorganisms growing in the tested carbohydrates, amino acids and organic acids, compounds present in root exudates (Kong et al., 2008), would support this observation. In fact, photosynthesized compounds released from rice roots to the soil can provide nutrients to increase the microbial populations (Bai et al., 2000). On the other hand, the addition of synthetic $\mathrm{N}$ fertilizers in paddy CONV may have also contributed to enhance the growth of the cultivable soil populations. Thus, the influence of root exudates may have been noticeable in paddy ORG because it did not receive fertilization or any other treatment after seeding.

Multivariate analysis of soil fingerprints is a useful tool to detect shifts in the microbial composition of organically and conventionally farmed soils, as well as temporal variations in each type of farming system. For instance Hartmann et al. (2006) reported significant differences in the microbial communities, characterized on basis of T-RFLP profiling, of organically and conventionally managed soils. However, the observed shifts were mainly due to the incorporation of farmyard manure (FYM), as the microbial communities of organically and conventionally managed soils with FYM amendment were similar. In a further study, Hartmann and Widmer (2006) reported highly similar microbial diversity indices values among unfertilised, organic and conventional FYM fertilised soils, whereas through the analysis of the composition of the communities by T-RFLP profiling and by sequence of 16S rRNA genomic libraries strong differences in composition were found. These findings led to the conclusion that changes in the microbial community structure may not lead to shifts in the diversity indices values, since some taxonomic groups may be compensated by modifications of others (Hartmann and Widmer, 2006). In another study, Bossio et al. (1998) detected highly significant differences in PLFA profiles between organically and conventionally farmed tomato soil plots and among sampling dates, while the Shannon's diversity index values based on PLFA relative abundance did not vary between farming system type neither over time. This observation, as in our study, may indicate the limitation of the Shannon's diversity index to assess microbial diversity on basis of fingerprinting data. Nevertheless, Fromin et al. (2002) in their comprehensive review on community analysis by DGGE patterning, refers
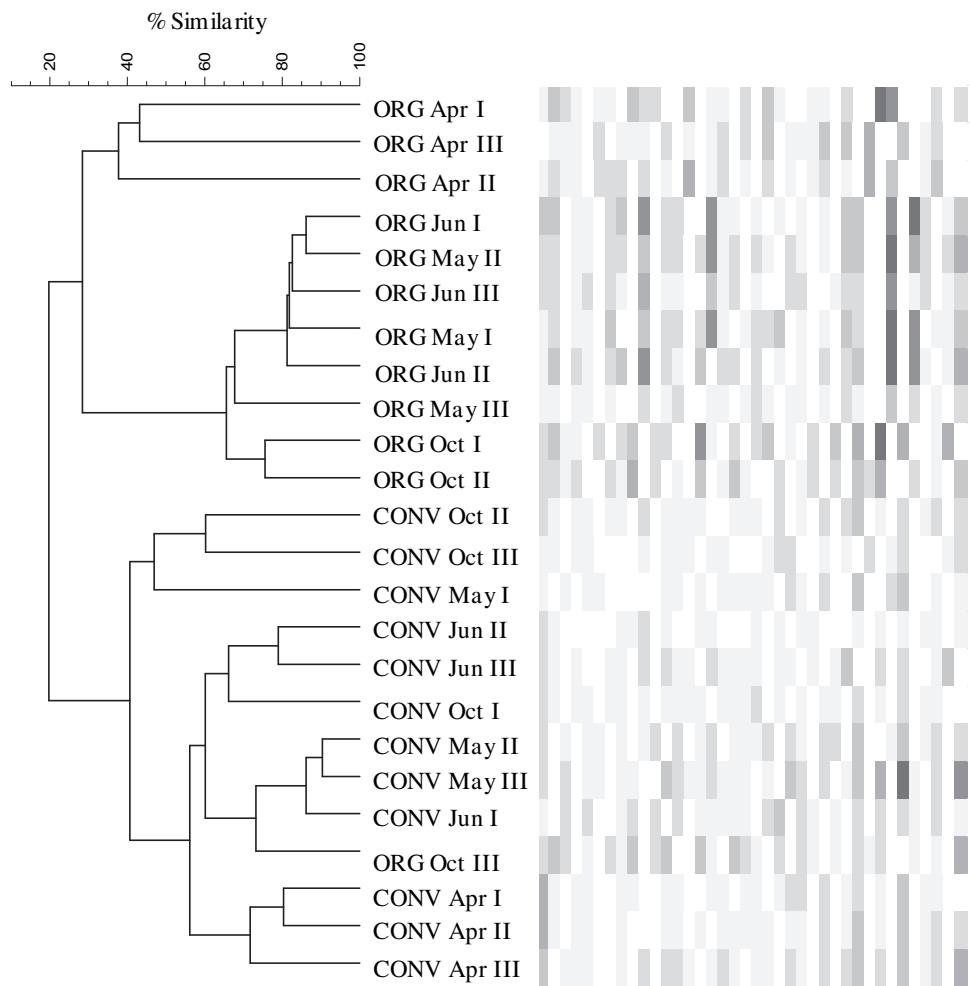

Band intensity $(0)$

Band intensity (1-3)

Band intensity (3-6)

Band intensity (7-9)

Band intensity (10-12)

Band intensity (13-15)

Band intensity (16-18)

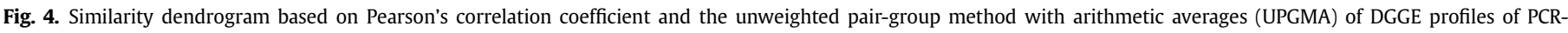
amplified 16S rDNA fragments of bacterial communities from paddy soils ORG and CONV. 


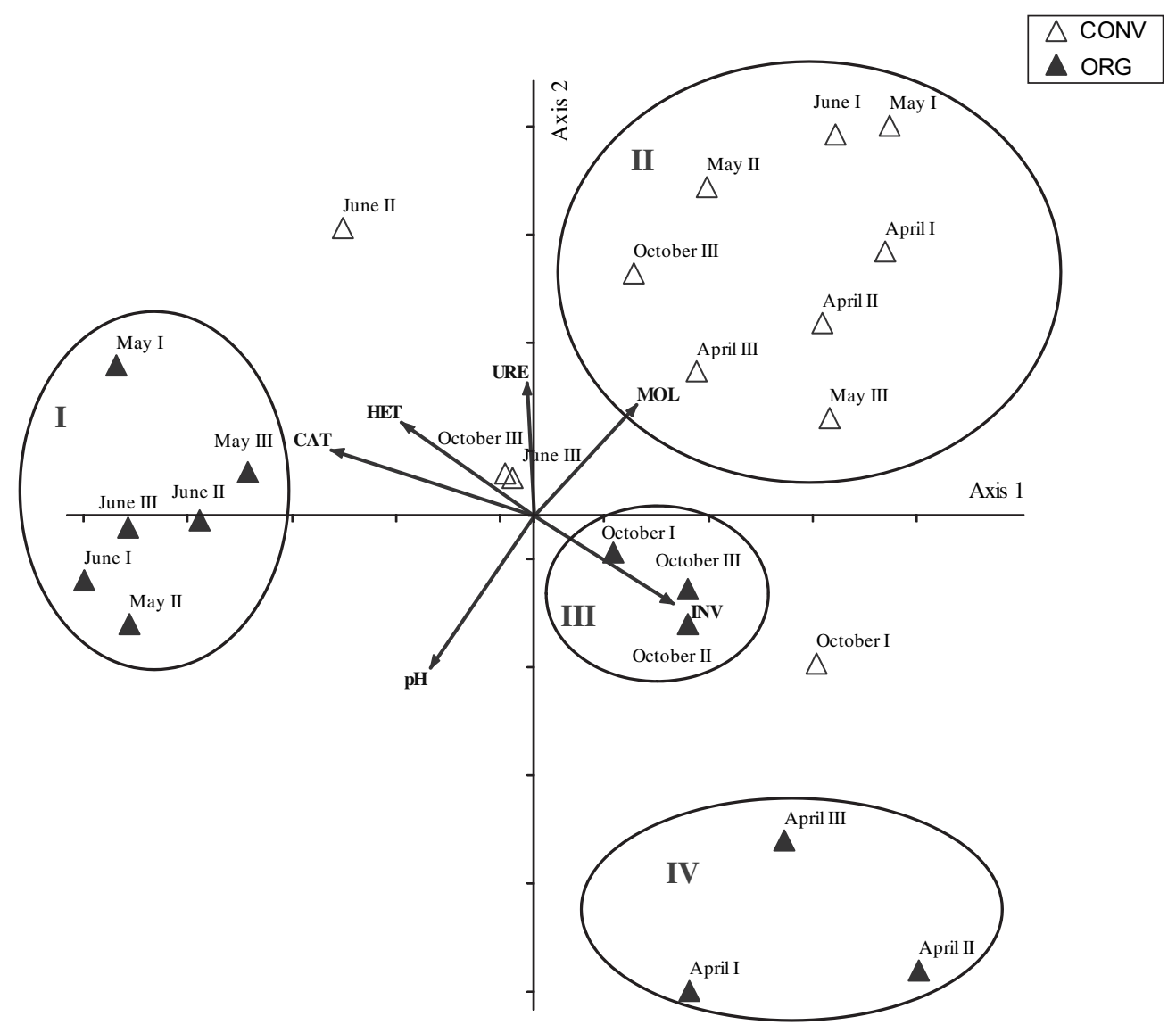

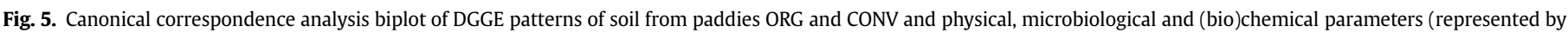

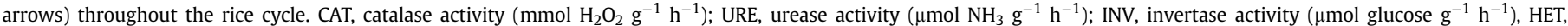

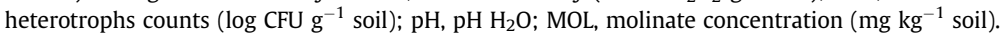

this index as a valuable tool. These observations reinforce the relevance of multivariate analyses to infer about temporal variations or farming systems. In fact, such analyses allowed an integrated interpretation of the data and revealed that the soil functional community structure presented similar temporal variations irrespective of the type of management, while the farming type influenced the bacterial community structure.

The CLPP patterns of paddies ORG and CONV varied over time in a similar manner, except for June. Parameters as the urease activity, which peaked in May, and the fungi counts, which presented high values in October, for both paddies may explain the separation of the functional community structure in these months. The catalase activity, which showed the lowest values in April, influenced the separation of the CLLP patterns of both paddies in this month. Dissimilar functional community structure in paddies ORG and CONV was mainly explained by the significant differences in the soil water content found in these paddies in June. Although also varying over time, in paddy ORG the DGGE patterns-based groups were slightly different from the CLPP-based groups. In this case, the bacterial community of May and June grouped together. The high catalase activity values and counts of heterotrophs found in May and June, and the high invertase activity values registered in April and October contributed to explain the variation observed between the communities of May/June and those of April and October. The lowest urease activity values and the highest values of $\mathrm{pH}$ influenced the separation of the DGGE profiles of paddy ORG in April. Similar results were obtained by Kikuchi et al. (2007) and by Watanabe et al. $(2006,2007)$ when analysing, respectively, the bacterial and methanogenic populations of rice soils with synthetic fertilization through PCR-DGGE rDNA or RT-PCR rRNA profiling over time. As we observed, those authors reported that although the number of DGGE bands did not fluctuate throughout the year, multivariate analysis showed that differences in bands intensity were sufficient to demonstrate that the period of rice cultivation influenced the bacterial and methanogenic communities (Kikuchi et al., 2007; Watanabe et al., 2006). Although the agricultural management of rice crop is not described by Min-Cheol et al. (2008), these authors reported also temporal variations in the microbial community based on PLFA profiles and of 165 rDNA clone libraries of rice field soil. Interestingly, the temporal variation in cultivable bacteria, actinomycetes and fungi described by MinCheol et al. (2008) between rice planting and one month after harvest is similar to that observed in the present study.

The DGGE profiles of paddy CONV, which presented a higher number of common bands at every analysed period than paddy ORG, formed a distinct group, which was correlated, among other factors, with the presence of molinate in the soil. When compared to paddy ORG, the bacterial community of the paddy CONV did not show temporal variation, suggesting that the bacterial community structure of both paddies was distinct at each sampling time. In fact, the cluster analyses of DGGE profiles of both paddies run in the same gel, for each of the analysed periods, showed that the DGGE patterns of paddies ORG and CONV always formed separated clusters (data not shown). The influence of the agricultural management procedures on the structure of the soil bacterial communities was, thus, demonstrated in the current study. Nevertheless, differences in land 
use may also have contributed to differentiate the bacterial community structure of both paddies, as paddy ORG was under production for only two years while paddy CONV was for six years. This study also evidenced the higher plasticity of the organically farmed rice soil bacterial community, given its higher responsiveness to temporal shifts than that observed in the conventionally farmed paddy.

In summary, it was observed that the microbial populations of rice field soil subjected to organic and conventional farming presented similar functional and bacterial richness and diversity, with temporal variations on the microbial density (cell counts), CLPP and enzymatic activity. Given these parameters may reflect the metabolic capabilities of the fast growing fraction of the bacterial community, our results suggest that this bacterial fraction seems to be less affected by the agronomic management than the total bacterial community, that was shown to differ between organically and conventionally farmed soil. On the other hand, functional redundancy of soil microorganisms may also explain the observed results.

\section{Conclusions}

The agricultural management practices were observed to influence the bacterial community structure but not the functional activity of bulk rice field soil. The organically farmed soil showed temporal variations in the functional and in the bacterial community structure. In the conventionally farmed soil similar temporal variations were observed in the functional, but not in the bacterial community structure. Altogether these results suggest functional redundancy of the microbial communities of organically and conventionally farmed rice field soil.

\section{Acknowledgements}

We gratefully acknowledge Professor Kornelia Smalla (Federal Research Centre for Cultivated Plants, Julius Kuehn Institute, Germany) for the technical guidance for DGGE analysis implementation, Serafim Andrade (DRAP Centro, Portugal) for valuable help in soil sampling and for giving all the information concerning the rice crop farming procedures and Diana Bello Currás and Ana Iglesias Tojo for their kind technical assistance. We acknowledge also Instituto Nacional de Recursos Biológicos, Departamento de Ciência do Solo da Estação Agronómica Nacional, Oeiras, Portugal, for the texture, physical and chemical soil analyses.

This work was financially supported by Fundação para a Ciência e a Tecnologia in the form of project POCI/AMB/59836/2004 and PhD grant SFRH/BD/44876/2008. Collaboration with researchers in Spain was possible thanks to the funding of the Ministerio de Ciencia e Innovación and the Xunta de Galicia (projects CTM200613862-C02-02 and PGIDIT07PXIB203009PR).

\section{References}

Asakawa, S., Kimura, M., 2008. Comparison of bacterial community structures at main habitats in paddy field ecosystem based on DGGE analysis. Soil Biology \& Biochemistry 40, 1322-1329.

Bai, Q., Gattinger, A., Zelles, L., 2000. Characterization of microbial consortia in paddy rice soil by phospholipid analysis. Microbial Ecology 39, 273-281.

Bossio, D.A., Scow, K.M., Gunapala, N., Graham, K.J., 1998. Determinants of soil microbial communities: effects of agricultural management, season, and soil type on phospholipid fatty acid profiles. Microbial Ecology 36, 1-12.

Brunk, C., Jones, K., James, T., 1979. Assay for nanogram quantities of DNA in cellular homogenates. Analytical Biochemistry 92, 497-500.

Camiña, F., Trasar-Cepeda, C., Gil-Stores, F., Leirós, M.C., 1998. Measurement of dehydrogenase activity in acid soils rich in organic matter. Soil Biology \& Biochemistry 30, 1005-1011
Carpenter-Boggs, L., Kennedy, A.C., Reganold, J.P., 2000. Organic and biodynamic management: effects on soil biology. Soil Science Society of America Journal 64, 1651-1659.

Castro, M., Silva-Ferreira, A.C., Manaia, C.M., Nunes, O.C., 2005. A case study of molinate application in a Portuguese rice field: herbicide dissipation and proposal of a clean-up methodology. Chemosphere 59, 1059-1065.

Cremonesi, L., Firpo, S., Ferrari, M., Righetti, P.G., Gelfi, C., 1997. Double-gradient DGGE for optimized detection of DNA point mutations. Biotechniques 22, 326-330.

Eltun, R., Korsaeth, A., Norhdheim, O., 2002. A comparison of environmental, soil fertility, yield, and economical effects in six cropping systems based on an 8-year experiment in Norway. Agriculture, Ecosystems and Environment 90, 155-168.

Fromin, N., Hamelin, J., Tarnawski, S., Roesti, D., Jourdain-Miserez, K., Forestier, N. Teyssier-Cuvelle, S., Gillet, F., Aragno, M., Rossi, P., 2002. Statistical analysis of denaturing gel electrophoresis (DGE) fingerprinting patterns. Environmental Microbiology 4, 634-643.

Gregorich, E.G., Carter, M.R., Angers, D.A., Monreall, C.M., Ellerta, B.H., 1994. Towards a minimum data set to assess soil organic matter quality in agricultural soils. Canadian Journal of Soil Science 74, 367-385.

Guitián-Ojea, F., Carballas, T., 1976. Técnicas de análisis de suelos. Santiago de Compostela, Pico Sacro.

Hartmann, M., Fliessbach, A., Oberholzer, H.-R., Widmer, F., 2006. Ranking the magnitude of crop and farming system effects on soil microbial biomass and genetic structure of bacterial communities. FEMS Microbiology Ecology 57, 378-388.

Hartmann, M., Widmer, F., 2006. Community structure analyses are more sensitive to differences in soil bacterial communities than anonymous diversity indices. Applied and Environmental Microbiology 72, 7804-7812.

Hasset, J.J., Banwart, W.L., 1992. Soils and Their Environment. Prentice-Hall, Inc. Englewood Cliffs, New Jersey.

Henckel, T., Jäckel, U., Conrad, R., 2001. Vertical distribution of the methanotrophic community after drainage of rice field soil. FEMS Microbiology Ecology 34 279-291.

Heuer, H., Krsek, M., Baker, P., Smalla, K., 1997. Analysis of actinomycete communities by specific amplification of gene encoding 16SrRNA and gel-electrophoretic separation in denaturing gradients. Applied and Environmental Microbiology 63 3233-3241.

Johnson, J.L., Temple, K.L., 1964. Some variables affecting the measurement of 'catalase activity' in soil. Soil Science Society of America Proceedings 28, 207-209.

Kennedy, A.C., 1994. Carbon utilization and fatty acid profiles for characterization of bacteria. In: Weaver, R.W., Angle, S., Bottomley, P., Bezdicek, D., Smith, S. Tabatabai, A., Wollum, A. (Eds.), Methods of Soil Analysis. Part 2: Microbiological and Biochemical Properties. Soil Science Society of America, Wisconsin, USA, pp. 546-556.

Kidd, P.S., Prieto-Fernández, A., Monterroso, C., Acea, M.J., 2008. Rhizosphere microbial community and hexachlorocyclohexane degradative potential in contrasting plant species. Plant and Soil 302, 233-247.

Kikuchi, H., Watanabe, T., Jia, Z., Kimura, M., Asakawa, S., 2007. Molecular analyses reveal stability of bacterial communities in bulk soil of a Japanese paddy field: estimation by denaturing gradient gel electrophoresis of 16S rRNA genes amplified from DNA accompanied with RNA. Soil Science and Plant Nutrition 53, 448-458.

Knowles, R., Barraquio, W.L, 1994. Free living dinitrogen-fixing bacteria. In: Weaver, R.W., Angle, S., Bottomley, P., Bezdicek, D., Smith, S., Tabatabai, A. Wollum, A. (Eds.), Methods of Soil Analysis. Part 2: Microbiological and Biochemical Properties. Soil Science Society of America, Wisconsin, USA, pp. 179-197.

Kong, C.H., Wang, P., Zhao, H., Xu, X.H., Zhu, Y.D., 2008. Impact of allelochemical exuded from allelopathic rice on soil microbial community. Soil Biology \& Biochemistry 40, 1862-1869.

Ladd, J.N., Butler, H.A., 1972. Short-term assays of soil proteolytic enzyme activities using proteins and dipeptide derivatives as substrates. Soil Biology \& Biochemistry 4, 19-30.

Liesack, W., Schnell, S., Revsbech, N.P., 2000. Microbiology of flooded rice paddies. FEMS Microbiology Reviews 24, 625-645.

Liu, B., Tu, C., Hu, S., Gumpertz, M., Ristaino, J.B., 2007. Effect of organic, sustainable, and conventional management strategies in grower fields on soil physical chemical, and biological factors and the incidence of Southern blight. Applied Soil Ecology 37, 202-214.

Manuel, C.M., Nunes, O.N., Melo, L.F., 2007. Dynamics of drinking water biofilm in flow/non-flow conditions. Water Research 41, 551-562.

Mader, P., Fliebbach, A., Dubois, D., Gunst, L., Fried, P., Niggli, U., 2002. Soil fertility and biodiversity in organic farming. Science 296, 1694-1697.

McCaig, A.E., Glover, L.A., Prosser, J.I., 2001. Numerical analysis of grassland bacterial community structure under different land management regimens by using $16 \mathrm{~S}$ ribosomal DNA sequence data and denaturing gradient gel electrophoresis banding pattern. Applied and Environmental Microbiology 67, 4554-4559.

Min-Cheol, K., Jae-Hyung, A., Hye-Chul, S., Taesung, K., Tae-Hun, R., Dong-Hern, K., Hong-Gyu, S., Lee, G.H., Ka, J.O., 2008. Molecular analysis of bacterial community structures in paddy soils for environmental risk assessment with two varieties of genetically modified rice, Iksan 483 and Milyang 204. Journal of Microbiology and Biotechnology 18, 207-218.

Nannipieri, P., Pedrazzini, F., Arcara, P.G., Piovanelli, C., 1979. Changes in aminoacids, enzyme-activities, and biomasses during soil microbial-growth. Soil Science 127, 26-34.

Nannipieri, P., Ceccanti, B., Cervelli, S., Matarese, E., 1980. Extraction of phosphatase, urease, proteases, organic carbon and nitrogen from soil. Soil Science Society of America 44, 1011-1016 
Nübel, U., Engelen, B., Felske, A., Snaidr, J., Wieshuber, A., Amann, R.I., Ludwig, W., Backhaus, H., 1996. Sequence heterogeneities of genes encoding 16S rRNAs in Paenibacillus polymyxa detected by temperature gradient gel electrophoresis. Journal of Bacteriology 178, 5636-5643.

Pielou, E.C., 1966. The measurement of diversity in different types of biologica collections. Journal of Theoretical Biology 13, 131-144.

Roger, P.A., Ladha, J.K., 1992. Biological $\mathrm{N}_{2}$ fixation in wetland rice fields: estimation and contribution to nitrogen balance. Plant and Soil 141, 41-55.

Schinner, F., von Mersi, W., 1990. Xylanase-, CM-cellulase- and invertase activity in soil: an improved method. Soil Biology \& Biochemistry 22, 511-515.

Seklemova, E., Pavlova, A., Kovacheva, K., 2001. Biostimulation-based bioremediation of diesel fuel: field demonstration. Biodegradation 12, 311-316.

Shannon, C.E., Weaver, W., 1963. The Mathematical Theory of Communication. University of Illinois Press, Urbana.

Sheng, Z.L., Min, L., Yong, H.C., Abid, S., 2005. Effects of nutrient and pest management on soil microorganism in hybrid rice double-annual cropping system. Communications in Soil Science and Plant Analysis 36, 1525-1536.

Shibahara, F., Inubushi, K., 1997. Effects of organic matter application on microbia biomass and available nutrients in various types of paddy soils. Soil Science and Plant Nutrition 43, 191-203.
Tabatabai, M., Bremner, J.M., 1970. Arylsulphatase activity of soils. Soil Science Society of America Proceedings 34, 225-229.

Trasar-Cepeda, C., Caminã, F., Leirós, M.C., Gil-Sotres, F., 1999. An improved method for measurement of catalase activity in soils. Soil Biology \& Biochemistry 31, 483-485.

van Diepeningen, A., Vos, O.J., Korthals, G.W., van Bruggen, H.C., 2006. Effects of organic versus conventional management on chemical and biological parameters in agriculture soils. Applied Soil Ecology 31, 120-135.

Watanabe, T., Kimura, M., Asakawa, S., 2006. Community structure of methanogenic archaea in paddy field soil under double cropping (rice-wheat). Soil Biology \& Biochemistry 38, 1264-1274.

Watanabe, T., Kimura, M., Asakawa, S., 2007. Dynamics of methanogenic archaeal communities based on rRNA analysis and their relation to methanogenic activity in Japanese paddy field soils. Soil Biology \& Biochemistry 39, 2877-2887.

Wind, T., Conrad, R., 1997. Localization of sulphate reduction in planted and unplanted rice field soil. Biogeochemistry 37, 253-278.

Zhong, W.H., Cai, Z.C., 2007. Long-term effects of inorganic fertilizers on microbia biomass and community functional diversity in a paddy soil derived from quaternary red clay. Applied Soil Ecology 36, 84-91.

Zhou, J., Guo, W., Wang, R., Han, X., Wang, Q., 2008. Microbial community diversity in the profile of an agricultural soil in northern China. Journal of Environmental Sciences 20, 981-988. 